\title{
The Effects of Area Enclosures on Rangeland Condition, Herbaceous Biomass and Nutritional Quality in Southeast Ethiopia
}

\author{
Mengistu Asrat, Ayana Angassa* and Aster Abebe
}

School of Animal and Range Sciences, College of Agriculture, Hawassa University, Hawassa, Ethiopia

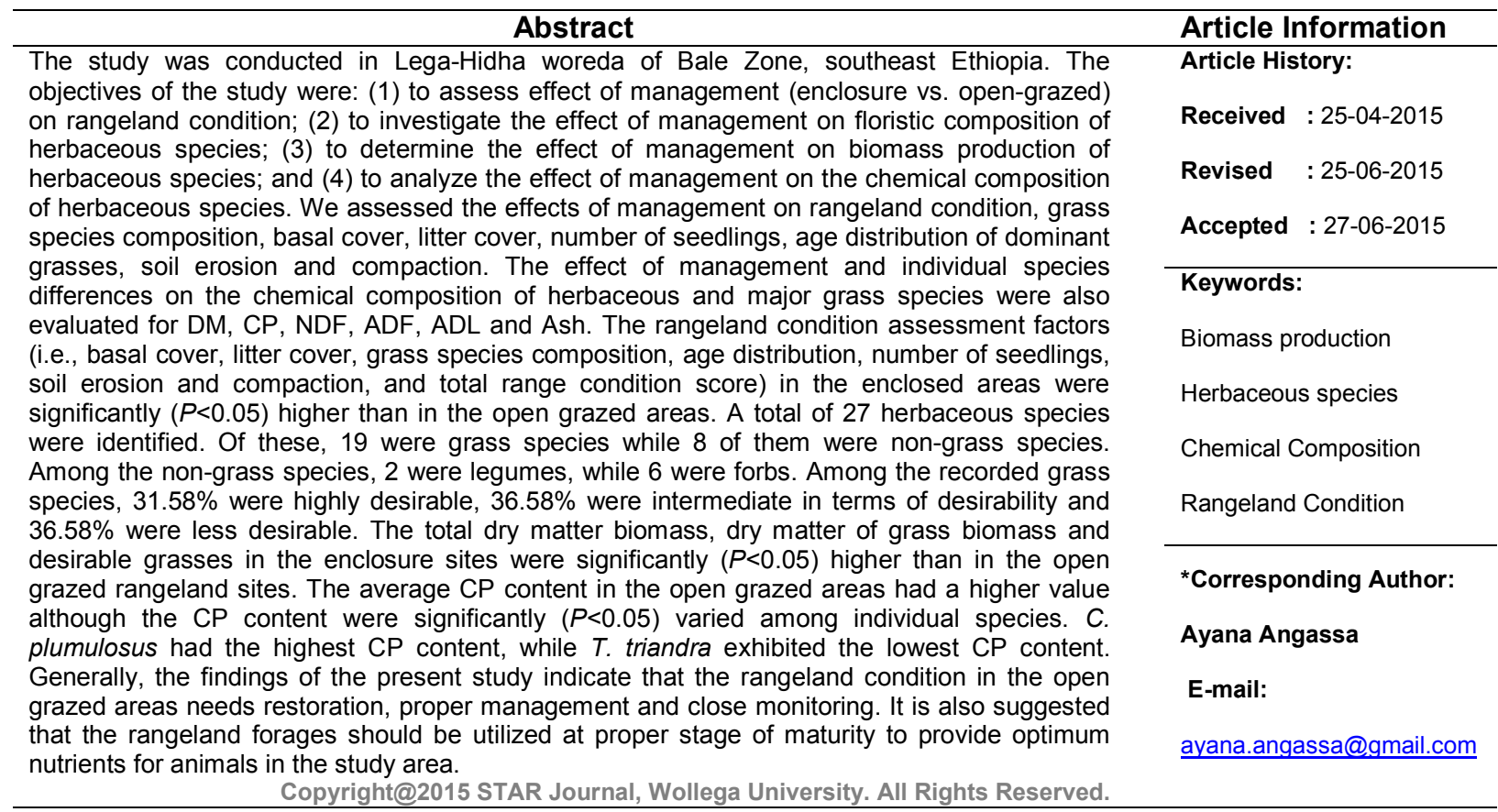

\section{INTRODUCTION}

Decline in rangeland resources and livestock productivity are among the most pressing problems worldwide (Oba et al., 2000). Increased grazing pressure and decline in the productivity of rangelands are a major threat to livestock production (Angassa, 2014), rangeland biodiversity (Angassa and Oba, 2010; Angassa et al., 2012) and local livelihood (Bekele et al., 2014). Dry rangelands are ecologically unstable with high variability of rainfall and fluctuating forage productivity. Consequently, the livelihood of billions of pastoralists living in the dry rangelands of the world is at risk due to the deteriorating condition of rangelands.

In Ethiopia, rangelands consist of mainly native vegetation (grass, forbs and woody plant species), which are major sources of feed for grazing and browsing animals (Gemedo et al., 2006). Despite all of these merits, rangeland productivity is threatened by various factors. Rangeland degradation and reduction in the capacity of grazing lands are a serious problem with considerable impact on the livelihood of pastoral communities in Ethiopia. Reduction in the capacity of rangelands due to increased population pressure and invasion of undesirable plant species has been identified as a major concern in the rangelands of the country (Oba et al., Angassa and Oba, 2008, 2010). Currently, the rangelands of the country are characterized by the invasion of bush encroachment with a general decline in forage production (Oba, 1998).

The rangelands may have limited capabilities in providing reasonable animal sustenance and production due primarily to adverse environmental conditions including low and seasonal rainfall, varying degrees of soil fertility, soil erosion, inadequate forage availability, lack of proper management of grazing lands and increasing number of livestock (Alemayehu, 2005). The Ethiopian rangelands are presently undergoing extensive deterioration both in quantity and quality (Ahmed, 2003; Amaha, 2006; Belaynesh, 2006; Desalew, 2008). 
Mengistu Asrat et al.,

Improper rangeland management may result in serious land degradation, reduced biodiversity, and decline in the nutritive values of forage plants and the gradual replacement of indigenous grasses by unpalatable species (Alemayehu, 2004; Amaha, 2006; Teshome, 2007).

According to Mekuria and Yami (2013), rangeland condition is a reflection of specific indicators such as plant species composition, vegetation cover (basal cover), forage production, land condition (soil erosion and compaction) and management practices at a particular land system. Decline in rangeland condition may be explained in terms of reduction in vegetation covers and palatable species, as well as increases in unpalatable plant species. Further signs of declines in rangeland condition may include: depletions in soil quality and nutrients due to various forms of soil erosion, soil compaction and deterioration of plant regeneration capacities of the soil seed banks that make restoration of degraded rangeland more difficult. Such sign of declines may be induced by continuous grazing without rest and lack of conservation measures (Angassa, 1999; Gemedo et al., 2006; Teshome, 2007; Desalew, 2008).

Livestock feed supply from natural pasture is characterized by seasonal fluctuation in total dry matter (DM) production and nutritional quality because of the distinct seasonal variation in plant growth, in relation to the annual rainfall pattern. The cumulative effects of grazing and bush encroachment are believed to cause a decline in herbaceous species (Oba et al., 2000). However, the impact of grazing on individual herbaceous species has been rarely investigated. Response of herbaceous species attributes such as biomass, basal cover, age distribution of dominant grasses, number of seedling and soil condition with respect to grazing gradients to different location and nutritional quality of herbaceous species was rarely investigated in the current study area.

Lega-Hidha woreda is located in the lowlands of Bale zone, southeast Ethiopia; where pastoralism and agropastoralism are the main land use systems and livestock are the main assets of the community. Pastoralists own different animal types including grazers and browsers irrespective of the condition of rangeland. According to Friedel (1991) assessment of a rangeland that composed of different vegetation component must incorporate three parameters of assessments (i.e., the herbaceous layer, soil and tree-shrubs layer). In the past, some attempts have been made by many scholars to determine rangeland condition of the country. However, compared with the vast rangeland areas of the country, there are only very limited studies; for example in south Ethiopia (Angassa, 1999; Oba et al., 2000, Gemedo et al., 2006, Solomon et al., 2006), in middle Rift valley (Amsalu and Baars, 2002, Abule et.al., 2007) in East Ethiopia (Amaha, 2006 ) in south east Ethiopia (Teshome, 2007). Although a recent study by Angassa and Oba (2010) in southern Ethiopia has reported the total dry matter production of herbaceous plants, information is still lacking on the nutritional quality of key herbaceous species.

The Lega-Hidha rangeland has been enclosed partly since the last three years by the local community. Identifying the existing forage species of the natural pasture and their nutritive value is the primary task in
Sci. Technol. Arts Res. J., April-June 2015, 4(2): 79-88

designing and implementing appropriate management interventions such as livestock feeding strategy. The benefit that the enclosure brings forward for livestock production in terms of range condition, herbaceous species composition, and dry matter biomass/production and chemical composition has not been studied so far. The information will help to effectively integrate natural resource conservation schemes with livestock production activities in an effort to efficiently and sustainably utilize the available pastoralist resource. Therefore, the specific objectives of the study were: (1)To assesses the rangeland condition in relation to grazing pressure (enclosure vs. open grazed areas) in Lega-Hidha woreda; (2) To investigate herbaceous species composition in enclosure vs. open rangelands in the study area; (3) To determine biomass production of herbaceous species in enclosure vs. open grazing rangelands; and (4) To evaluate the chemical composition of major herbaceous species in the study area.

\section{MATERIALS AND METHODS}

\section{Description of the Study Area}

The study was carried out in Lega-Hidha woreda, Bale Zone of Oromia Regional State, Ethiopia. Lega-Hidha woreda is located between $7^{\circ} 45^{\prime} \mathrm{N} 41^{\circ} 15^{\prime} \mathrm{E}$ and at about $678 \mathrm{~km}$ south east of Addis Ababa. It covers an area of about $6157.15 \mathrm{~km}^{2}$ (PDSA, 2004). The climate in the area is arid or semi-arid. The rainfall pattern is bimodal type. The main rainy season is from April to June while the short rainy season is from August to September. The mean annual rainfall is ranging from 500 to $800 \mathrm{~mm}$. The woreda has an elevation ranging from 1200 to 1400 masl with average temperature between 25 and $28^{\circ} \mathrm{C}$. The main soil types are sandy and pellic vertisols. The human population of the woreda is estimated at 70,654 .

Pastoralism and agro-pastoralism are an integral part of the land use system in the woreda. According to PDSA (2004) livestock production (i.e., cattle, sheep, goats, camels, horses, mules and donkey rearing) is a common practice in the lowland areas of Bale Zone. Teff, maize, sorghum and wheat are the main cultivated crops for subsistence. Livestock feed resources in the study areas included natural pasture, shrubs, tree leaves, crop residues and hay.

\section{Site Selection}

To conduct this study, three rangeland sites (kebele) [i.e., Delo-Jano-Gubisa (D/J/Gubisa), Dereba and Beltu] were selected from the woreda in consultation with community representatives (elders), experts, supervisors and development agents from the Pastoralist Area Development office. These rangeland sites were selected based on grazing pressure, potential rangeland areas, management practices, similarity in slope and soil type of the sites. The woreda land use and land cover digital map was used to select the grazing areas (Figure 1).

Each rangeland site included two levels of grazing pressure (enclosure vs. open grazed) replicated twice. Enclosure areas refer to protected grazing lands that are reserved by the local community. The selection of individual enclosure was accomplished with the participation of the local communities, where each enclosure was protected for more than three years. Adjacent open-grazed areas were used as a control for each enclosed area. Open-grazed areas are communal grazing lands which are generally exposed to various 
Mengistu Asrat et al.,

impacts such as mismanagements due to the fact that it is out of the control of the communities (personal observation and discussion with the local community).
Sci. Technol. Arts Res. J., April-June 2015, 4(2): 79-88

Within enclosure areas and adjacent open-grazed areas, herbaceous species composition and yield were assessed using $1 \mathrm{~m}^{2}$ quadrant at $30 \mathrm{~m}$ interval.

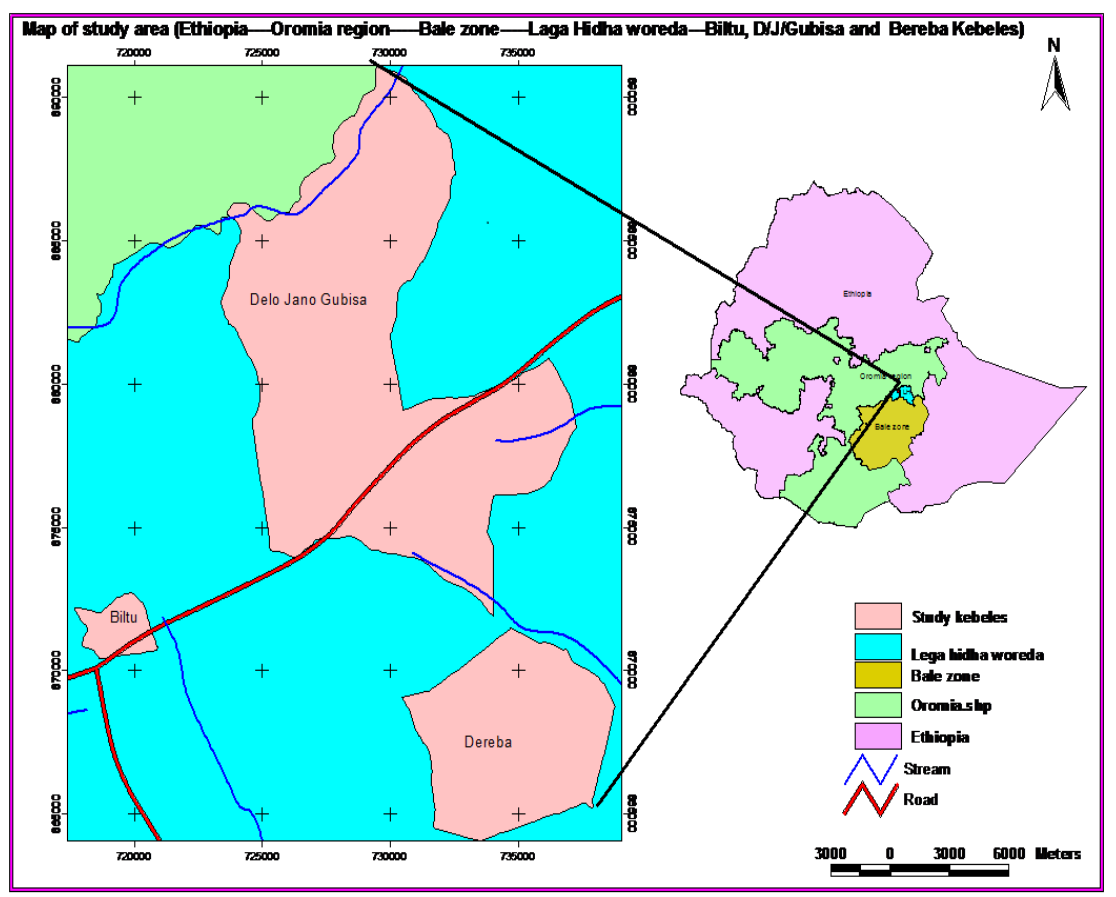

Figure 1: Map of the study site

\section{Rangeland Condition Assessment}

Rangeland condition assessment was conducted after the main rainy season in May when most grass species were at full flowering stage, which is important for the identification of floristic composition. The range condition assessment covered two categories of grazing pressure (enclosure vs. open grazed areas). Then, each sampling plot was designed to cover enclosure versus open grazed sites. Range condition assessment was performed at the same sampling plots within each categories of grazing pressure.

\section{Range Condition Indicators}

The factors considered for range condition scores were based on the criteria adopted by Baars et al. (1997). The maximum possible score was 50 points. Range condition score was interpreted as excellent (41-50 points), good (31-40 points), fair (21-30 points), poor (11-20 points) or very poor (3-10 points).

\section{Grass Species Composition}

Grass species composition as an indicator of range condition was studied in the month of May based on visual observation. For grass species composition, one to ten points were considered according to the methods shown in Table 1. Then, the grass species were divided into desirable species likely to decline with heavy grazing pressure (decreasers), intermediate species likely to increase with heavy grazing pressure (increasers), and undesirable species likely to invade with heavy grazing pressure (invaders) as suggested by Tainton, (1981). Classification of grasses into decreasers, increasers and invaders was done with the consultation of the local community members during group discussion about the palatability and distribution of each identified grass species in relation to grazing pressure and cross checking with the list of grasses from the book (Fromann and Person, 1974). The proportion and score for each species was assessed visually at a $30 \mathrm{~m}$ interval along each transact.

\section{Basal and Litter Cover}

Basal cover and litter cover were assessed on a scale of $0-10$ points (Table 1). A representative sample area of $1 \mathrm{~m}^{2}$ was selected for detailed assessment of both basal and litter covers. The surface of the basal cover of tufted grasses and their distribution were assessed for $1 \mathrm{~m}^{2}$ areas, which were divided into two equal parts. One of the halves was further divided into eighths. All grasses in the selected $1 \mathrm{~m}^{2}$ were removed and transferred onto the eighth fraction unit of the original $1 \mathrm{~m}^{2}$ in order to facilitate visual estimation of the percentage of the basal covers within one-eighth of the $1 \mathrm{~m}^{2}$. Only the basal covers of the living parts of grasses were considered. Scores for the basal cover of tufted grasses were considered excellent when the one- eighth fractional unit was completely filled (12.5 per cent) with the transferred grass basal cover (Baars et al., 1997). Basal cover was considered very poor at $<3$ percent cover. The rating for litter covers within the same $1 \mathrm{~m}^{2}$ was considered excellent when it exceeded 40 per cent and poor at $<10$ per cent litter cover (Table 1).

\section{Number of Seedlings and Age Distribution}

The number of seedling and age distribution was made according to Baars et al. (1997). For both the number of seedlings and age distribution of dominant grasses, score of $1-5$ a point was used (Table 1). The number of seedlings was counted using three areas, each equal to the size of an A4 sheet of paper $(30 \mathrm{~cm} \times 21 \mathrm{~cm})$ sampled at random. A maximum score of five points was given when all age categories of grasses (i.e., young, 
Mengistu Asrat et al.,

medium and old) were present (Table 1). For the purpose of this study, age categories of grasses were defined as follow: (i) the term young refers to species at their early stage of growing before flowering; (ii) medium age refers to those species at flowering stage; and (iii) old refers to perennial grass species after flowering and/or those from the previous season when encountered in each sampling plot.

\section{Soil Erosion and Compaction}

Soil erosion was based on the amount of pedestals (higher part of soils held together by plant roots, with eroded soil around the tuft), and in severe cases, the presence of pavements (terraces of flat soil, normally
Sci. Technol. Arts Res. J., April-June 2015, 4(2): 79-88

without basal cover, with a line of tufts between pavements) if there is no sign of soil erosion (no soil movement), a maximum score of 5 was given and a minimum score of 0 was given in situations where gully formation was observed due to soil erosion. The occurrence of slight sand mulch, slope-sided pedestals, steep-sided pedestals and pavements coincided with scores of 4, 3, 2 and 1, respectively. Soil compaction was based on the amount of capping (crust formation). If there was no compaction, a maximum score of 5 was given and the score decreased with increasing capping of the soil. Scores of $4,3,2$ and 1 were given for soils with isolated capping, > $50 \%$ capping, > $75 \%$ capping and almost 100 $\%$ capping, respectively (Angassa, 2014).

Table 1: Methods for range condition assessment and scoring in arid to semi-arid rangelands

\begin{tabular}{|c|c|c|c|c|c|c|c|}
\hline GC & BC & LC & NS & AD & SC & SE & Score \\
\hline $\begin{array}{l}\text { 91-100 percent } \\
\text { decreaser }\end{array}$ & $\begin{array}{l}>12 \text { per cent } \\
\text { no bare spot }\end{array}$ & $\begin{array}{c}>40 \text { per } \\
\text { cent }\end{array}$ & & & & & 10 \\
\hline $\begin{array}{l}81-90 \text { percent } \\
\text { decreasers }\end{array}$ & $\begin{array}{l}>12 \text { per cent } \\
\text { slightly bare } \\
\text { spots }\end{array}$ & & & & & & 9 \\
\hline $\begin{array}{l}\text { 71-80 percent } \\
\text { decreasers }\end{array}$ & $\begin{array}{l}>9 \text { percent } \\
\text { evenly } \\
\text { distributed }\end{array}$ & $\begin{array}{l}11-40 \text { per } \\
\text { cent and } \\
\text { evenly } \\
\text { distributed }\end{array}$ & & & & & 8 \\
\hline $\begin{array}{l}61-70 \text { percent } \\
\text { decreasers }\end{array}$ & $\begin{array}{l}>9 \text { percent } \\
\text { occasional } \\
\text { bare spots }\end{array}$ & & & & & & 7 \\
\hline $\begin{array}{l}\text { 51-60 percent } \\
\text { decreasers }\end{array}$ & $\begin{array}{l}>6 \text { percent } \\
\text { evenly } \\
\text { distributed }\end{array}$ & $\begin{array}{l}11-40 \text { per } \\
\text { cent and } \\
\text { unevenly } \\
\text { distributed }\end{array}$ & & & & & 6 \\
\hline $\begin{array}{l}41-50 \text { percent } \\
\text { decreasers }\end{array}$ & $\begin{array}{l}>6 \text { percent } \\
\text { bare spots }\end{array}$ & & $\begin{array}{c}>4 \\
\text { seedlings }\end{array}$ & $\begin{array}{l}\text { All age } \\
\text { categories }\end{array}$ & No sign of erosion & $\begin{array}{l}\text { No sign of } \\
\text { compaction }\end{array}$ & 5 \\
\hline $\begin{array}{l}10-40 \text { percent } \\
\text { decreasers and } \\
\geq 30 \text { percent } \\
\text { increasers }\end{array}$ & $\begin{array}{l}>3 \text { percent } \\
\text { mainly } \\
\text { perennials }\end{array}$ & $\begin{array}{l}\text { 3-10 } \\
\text { percent } \\
\text { mainly of } \\
\text { grasses }\end{array}$ & $\begin{array}{c}4 \\
\text { seedling }\end{array}$ & $\begin{array}{l}\text { Two size } \\
\text { category } \\
\text { present }\end{array}$ & Slight sand mulch & $\begin{array}{l}\text { Isolated } \\
\text { capping }\end{array}$ & 4 \\
\hline $\begin{array}{l}10-40 \text { percent } \\
\text { decreasers and } \\
<30 \text { percent } \\
\text { increasers }\end{array}$ & $\begin{array}{l}\text { >3percent } \\
\text { mainly of } \\
\text { annuals }\end{array}$ & & $\begin{array}{c}\quad 3 \\
\text { Seedlings }\end{array}$ & $\begin{array}{l}\text { Present } \\
\text { only } \\
\text { old }\end{array}$ & $\begin{array}{l}\text { Slope side pedestals } \\
\text { (>50 per cent } \\
\text { capping })\end{array}$ & $\begin{array}{l}>50 \text { per } \\
\text { cent } \\
\text { capping }\end{array}$ & 3 \\
\hline $\begin{array}{l}<10 \text { percent } \\
\text { decreasers and } \\
\geq 50 \text { percent } \\
\text { increasers }\end{array}$ & $\begin{array}{l}1-3 \text { percent } \\
\text { basal cover }\end{array}$ & $\begin{array}{c}3-10 \\
\text { percent } \\
\text { weeds or } \\
\text { tree leaves }\end{array}$ & $\begin{array}{c}2 \\
\text { Seedling }\end{array}$ & $\begin{array}{l}\text { Only } \\
\text { Medium }\end{array}$ & $\begin{array}{c}\text { Steep-sided } \\
\text { pedestals }(>75 \text { per } \\
\text { cent capping })\end{array}$ & $\begin{array}{l}>75 \text { per } \\
\text { cent } \\
\text { capping }\end{array}$ & 2 \\
\hline $\begin{array}{l}<10 \text { percent } \\
\text { decreasers } \\
\text { and }<50 \text { percent } \\
\text { increasers }\end{array}$ & $\begin{array}{l}<1 \text { percent } \\
\text { basal cover }\end{array}$ & & $\begin{array}{c}1 \\
\text { Seedling }\end{array}$ & $\begin{array}{l}\text { Only } \\
\text { young }\end{array}$ & $\begin{array}{l}\text { Pedestals (almost } \\
100 \text { capping) }\end{array}$ & $\begin{array}{l}\text { Almost } 100 \\
\text { per cent } \\
\text { capping }\end{array}$ & 1 \\
\hline Bare ground & 0 percent & $\begin{array}{c}<3 \text { per } \\
\text { cent cover }\end{array}$ & $\begin{array}{c}\text { No } \\
\text { seedling }\end{array}$ & & Gullies & & 0 \\
\hline
\end{tabular}

GC, grass composition; BC, basal cover; LC, litter cover; NS, number of seedlings; AD, age distribution; and SC, soil condition. Source: (Baars et al., 1997)

\section{Assessment of Species Composition}

Herbaceous species composition assessment was conducted after the main rainy season during the month of May where most plant species were in full flowering stage. Herbaceous species composition was assessed in relation to grazing pressure (enclosures vs. open grazed areas) in three rangeland sites in Lega-Hidha woreda. Each rangeland site included two levels of grazing pressure (enclosure vs. open-grazed areas) replicated twice. From each sample site, herbaceous species compositions were assessed using $1 \mathrm{~m}^{2}$ quadrant at an interval of $30 \mathrm{~m}$ along transact.
Ten quadrants of $1 \mathrm{~m} \times 1 \mathrm{~m}$ per transect were sampled and individual species identified per quadrant and hand cutting was performed at ground level. After harvesting, samples of individual herbaceous species were weighed and total fresh weight was taken using a digital balance immediately. Then, samples were transferred into properly labeled paper bags and fastened at the top. The samples were kept under shade until sampling for the day was completed. Thereafter, samples were transported to Hawassa University, Animal Nutrition Laboratory and oven dried at $65 \mathrm{C}$ for $48 \mathrm{~h}$ for chemical composition determination. On the basis of the DM weights obtained, the actual weight of each individual herbaceous species was calculated. 
Mengistu Asrat et alo,

The following scales were used to designate the level of occurrence and distribution of grasses within each sampling plot on the basis of DM in terms of percent composition. These include: (i) dominant- when species scored $\geq 20$ percent of the DM at a site; (ii) commonwhen the score for species was $\geq 5$ percent and $<20$ percent of the DM; and (iii) a species was consideredpresent when the score was $<5$ percent of the DM.

\section{Biomass Production}

Harvested samples from each quadrant $\left(1 \mathrm{~m}^{2}\right)$ of study site were separated into sub-samples of grasses, legumes; forbs in the field and the fresh weight of individuals of each group were taken using a digital balance. Also after oven dried at $65^{\circ} \mathrm{C}$ for $48 \mathrm{~h}$, determination of biomass production of grass, legume and forbs were accomplished. Grasses were further categorized into highly desirable, intermediate desirable and less desirable for determination of biomass.

\section{Chemical Composition of Herbaceous Species}

The oven dried samples were ground in a Willey mill to pass through $1 \mathrm{~mm}$ sieve for the determination of chemical composition. Feed samples were analyzed for DM and ash using the method of AOAC (2000). Nitrogen was determined using the micro-Kjeldahl method (AOAC, $2000)$. Crude protein (CP) was calculated as $N \times 6.25$. The neutral detergent fiber (NDF), acid detergent fiber (ADF) and acid detergent lignin (ADL) were analyzed according to Van Soest and Robertoson (1985).

\section{Data Analysis}

Grass composition, basal cover, litter cover, age distribution of dominant grasses, numbers of seedlings
Sci. Technol. Arts Res. J., April-June 2015, 4(2): 79-88

and soil condition, as well as biomass of herbaceous species were considered as numerical response variables. Descriptive statistics were used to describe the herbaceous species composition. The data generated from this study were stratified into study site and grazing pressure (enclosure vs. open grazed) and analyzed using the General Liner Model (GLM) procedure in Statistical Package for Social Science (SPSS version 16) program. Post-hoc t-test was employed to compare mean differences. To test the effect of management on rangeland condition, biomass production, chemical composition of herbaceous sample, analysis of variance (ANOVA) was carried out using the following model.

\section{RESULTS}

\section{The Effect of Enclosure on Range Condition}

The effect of enclosure on range condition parameters is presented in Table 2. Grass species composition for the enclosure sample sites was not significantly $(P>0.05)$ different from open grazed sites except for Delo/J/Gubisa (Table 2). The enclosure areas had a significantly higher $(P<0.05)$ score values for basal cover, litter cover, number of seedlings and age distribution of dominant grasses than the open-grazed areas across the three sites (Table 2).

Soil erosion and compaction were significantly $(P<$ $0.05)$ higher in the open-grazed areas than in the enclosure areas across all the study sites. The overall range condition score was in the range of 16.1 (i.e., under poor condition) to 33.4 (good condition) and the difference was significant $(P<0.05)$ (Table 2$)$.

Table 2: Range condition scores (Mean \pm SE) of enclosure vs. open-grazed areas in Lega-Hidha woreda of Bale Zone, Ethiopia

\begin{tabular}{|c|c|c|c|c|c|c|}
\hline \multirow[b]{2}{*}{ Parameter } & \multicolumn{2}{|c|}{ Deraba } & \multicolumn{2}{|c|}{ D/J/Gubisa } & \multicolumn{2}{|c|}{ Beltu } \\
\hline & Enclosure & $\begin{array}{c}\text { Open } \\
\text { grazed }\end{array}$ & Enclosure & $\begin{array}{c}\text { Open } \\
\text { Grazed }\end{array}$ & Enclosure & $\begin{array}{c}\text { Open } \\
\text { Grazed }\end{array}$ \\
\hline Grass composition & $6.95 \pm 0.60^{a}$ & $5.70 \pm 0.65^{a}$ & $7.75 \pm 0.62^{a}$ & $6.40 \pm 0.49^{b}$ & $5.95 \pm 0.16^{a}$ & $6.20 \pm 0.64^{a}$ \\
\hline Basal cover & $6.35 \pm 0.48^{\mathrm{a}}$ & $2.70 \pm 0.21^{b}$ & $6.15 \pm 0.36^{\mathrm{a}}$ & $2.80 \pm 0.22^{b}$ & $6.10 \pm 0.39^{a}$ & $2.35 \pm 0.39^{b}$ \\
\hline Litter cover & $4.20 \pm 0.68^{\mathrm{a}}$ & $0.00 \pm 0.00^{b}$ & $7.00 \pm 0.29^{a}$ & $0.00 \pm 0.00^{b}$ & $6.10 \pm 0.59^{\mathrm{a}}$ & $0.00 \pm 0.00^{b}$ \\
\hline Noumber of seedling & $2.40 \pm 0.21^{\mathrm{a}}$ & $0.00 \pm 0.00^{b}$ & $2.15 \pm 0.26^{a}$ & $0.00 \pm 0.00^{b}$ & $2.50 \pm 0.21^{\mathrm{a}}$ & $0.00 \pm 0.00^{b}$ \\
\hline Age distribution & $4.00 \pm 0.10^{\mathrm{a}}$ & $2.70 \pm 0.22^{b}$ & $4.00 \pm 0.00^{a}$ & $4.00 \pm 0.00^{a}$ & $4.00 \pm 0.00^{\mathrm{a}}$ & $3.75 \pm 0.14^{b}$ \\
\hline Soil erosion & $3.25 \pm 0.16^{a}$ & $2.20 \pm 0.15^{b}$ & $3.00 \pm 0.17^{\mathrm{a}}$ & $2.15 \pm 0.15^{b}$ & $3.20 \pm 0.2^{\mathrm{a}}$ & $1.95 \pm 0.16^{b}$ \\
\hline Soil compaction & $3.60 \pm 0.11^{\mathrm{a}}$ & $2.80 \pm 0.12^{b}$ & $3.35 \pm 0.15^{\mathrm{a}}$ & $2.60 \pm 0.11^{\mathrm{b}}$ & $3.50 \pm 0.11^{\mathrm{a}}$ & $2.75 \pm 0.09^{b}$ \\
\hline Total score & $30.7^{\mathrm{a}}$ & $16.1^{\mathrm{b}}$ & $33.4^{\mathrm{a}}$ & $17.95^{\mathrm{b}}$ & $31.35^{\mathrm{a}}$ & $17^{\mathrm{b}}$ \\
\hline
\end{tabular}

\section{Effect of Enclosure on Herbaceous Species Composition}

The herbaceous species composition in the study sites is shown in Tables 3 and 4 . A total of 27 herbaceous species were recorded. Out of the total herbaceous species, 19 grasses, 2 legume species and 6 forbs species were recorded both in enclosures and opengrazed sites (Table 3). Grass species were accounted for $70.4 \%$ of the total herbaceous species with $31.6 \%$ of the grass species were highly desirable, $36.58 \%$ were intermediate in terms of desirability and $31.58 \%$ were less desirable (Table 3 ). At the time of sampling, herders mentioned that $B$. inscuipta, $B$. humidcola, $C$. ciliaris, $C$. plumulosus and $P$. maximum were highly palatable grass species. Herders also reported that $C$. pycnothrix, $D$. villosa, $H$. hirta, S. paradox and $T$. triandra were species of moderate palatability. The remaining grass species were considered by herders as species of low palatability. Overall, B. inscuipta, B. humidcola, C. plumulosus, $H$. hirta, $H$. contortus and $T$. triandra were among the dominant and/or common grass species recorded in the study areas. The results of the present study showed that the proportion of herbaceous legumes in the sample sites was generally very low (Table 3 ). In the enclosure and open-grazed areas, herbaceous species abundance was comparable. 
Table 3: Herbaceous species and their life forms, desirability and distribution in \% within enclosures and open-grazed areas of Lega-Hidha woreda, Bale zone, Ethiopia

\begin{tabular}{|c|c|c|c|c|c|c|c|c|}
\hline \multirow{2}{*}{$\begin{array}{c}\text { Herbaceous } \\
\text { species composition }\end{array}$} & \multirow{2}{*}{$\begin{array}{l}\text { Life } \\
\text { time }\end{array}$} & \multirow{2}{*}{$\begin{array}{l}\text { Desira- } \\
\text { blity }\end{array}$} & \multicolumn{2}{|c|}{ Delo/J/Gubisa } & \multirow{2}{*}{$\frac{\text { Deraba }}{\text { Enclosure }}$} & \multicolumn{3}{|c|}{ Beltu } \\
\hline & & & Enclosure & $\begin{array}{l}\text { Open- } \\
\text { grazed }\end{array}$ & & $\begin{array}{l}\text { Open- } \\
\text { grazed }\end{array}$ & Enclosure & $\begin{array}{l}\text { Open- } \\
\text { grazed }\end{array}$ \\
\hline \multicolumn{9}{|l|}{ Grasses } \\
\hline Bothriochloa inscuipta & $\mathrm{P}$ & HD & 20.875 & 12.815 & 15.2 & 14.875 & 4.995 & 12.95 \\
\hline Brachiaria humidcola & $A$ & HD & - & 2.60 & 8.5 & - & 2.52 & 9.25 \\
\hline Cenchrus ciliaris & $P$ & HD & 0.18 & - & 1.05 & 0.215 & - & 1.3 \\
\hline Chloris pycnothrix & A & ID & 0.855 & - & - & - & - & - \\
\hline Chrysopogon plumulosus & $P$ & HD & 20.45 & 7.24 & 2.25 & 18.035 & 0.595 & 2.63 \\
\hline Cynodon dactylon & $P$ & ID & - & 0.565 & - & - & - & - \\
\hline Digitaria villosa & $P$ & ID & 2.515 & 2.97 & - & 1.415 & 0.255 & - \\
\hline Enteropogon macrostachyus & $P$ & LD & - & 1.02 & - & - & - & - \\
\hline Eragrostis ciliaris & A & ID & - & - & 2.25 & - & 0.21 & 2.77 \\
\hline Heteropogon contortus & $P$ & LD & 18.99 & 27.595 & 10.15 & 35.9 & 79.905 & 11.09 \\
\hline Hyparrhenia Hirta & $P$ & ID & - & 6.645 & 7.2 & - & 1.155 & 6.31 \\
\hline Microchloa kunthii & $P$ & LD & 0.155 & - & - & - & - & - \\
\hline Panicum maximum & $P$ & HD & - & - & - & - & - & - \\
\hline Setaria paradox & A & ID & - & - & 24.4 & - & - & 24.64 \\
\hline Sporobolus pyramidalis & $P$ & LD & - & 5.14 & 2.65 & 0.155 & 0.36 & 2.42 \\
\hline Sporobulus festivus & $P$ & LD & - & - & - & - & - & - \\
\hline Tetrapogon cenchriformis & $P$ & ID & - & - & & 2.65 & - & - \\
\hline Themeda Triandra & $P$ & ID & - & 30.28 & 6.6 & 19.22 & 8.05 & 8.36 \\
\hline Tragus berternianus & $\mathrm{A}$ & LD & - & - & - & 0.13 & - & - \\
\hline \multicolumn{9}{|l|}{ Legumes } \\
\hline Crotalaria spinosa & $P$ & LD & 0.225 & - & - & 0.365 & - & - \\
\hline Tephrosia spps & $\mathrm{P}$ & HD & 7.17 & 0.77 & - & 0.96 & 0.405 & 0.13 \\
\hline \multicolumn{9}{|l|}{ Others/forbs } \\
\hline Achyranthus aspera $L$. & $P$ & LD & 10.715 & 1.57 & 16.25 & 1.97 & 0.285 & 15.03 \\
\hline Belpharis spps & $P$ & $\mathrm{HD}$ & 4.095 & & & 0.145 & & \\
\hline Commelina benghalensis $L$. & & & 0.315 & & & & & 0.15 \\
\hline Cyperus rotandus & $\mathrm{P}$ & LD & - & 0.785 & 1.75 & - & 0.81 & 1.76 \\
\hline Ocimum basilicum & $A$ & $\mathrm{HD}$ & 0.855 & - & - & 1.175 & 0.02 & - \\
\hline Sida ovata Forssk. & $\mathrm{P}$ & ID & 12.605 & - & 1.75 & 2.655 & 0.285 & 1.36 \\
\hline
\end{tabular}

$\mathrm{HD}=$ highly desirable, $\mathrm{ID}=$ intermediate desirable, $\mathrm{LD}=$ less desirable, $\mathrm{A}=$ annual and $\mathrm{P}=$ perennial

The current result showed that species abundance within the enclosures and open-grazed areas varied from three to five species per $1 \mathrm{~m}^{2}$. The dry weight of individual species both in the enclosures and open-grazed areas is presented in Table 4. Certain grass species were adapted to specific range site. C. pycnothrix, M. kunthii, $T$. berternianus and $C$. rotandus were found commonly in the open-grazed sites (Table 4). In the enclosure sampling plots, B. inscuipta, B. humidcola, C. plumulosus $H$. contortus and $T$. triandra were the dominant and/or common grass species recorded with higher proportions than other species (Table 4). In enclosure and opengrazed areas, palatable species, such as $B$. humidcola, $B$. inscuipta, $C$. plumulosus (decreasers) and the low palatable $H$. contortus (increasers) were commonly recorded.

The Effect of Enclosure on Dry-matter Yield of Herbaceous Species

The total DM yield of all herbaceous samples and that of grasses were significantly $(P<0.05)$ higher in the enclosures than in the open-grazed areas across all studied sites (Table 5). Similarly, the DM yield of grasses with intermediate desirability and DM yield of less desirable grasses in area enclosures were significantly $(P<0.05)$ higher than open-grazed areas except at Beltu and Delo/J/Gubisa sites. The total dry matter yield was decreased considerably from $152.07 \mathrm{~g} \mathrm{~m}^{-2}$ to $11.40 \mathrm{~g} \mathrm{~m}^{-2}$ as the range condition deteriorates from good within enclosures to poor condition along the open-grazed areas. Legumes and forbs did not significantly $(P>0.05)$ differ between enclosure and open-grazed sites. Similarly, highly desirable grass species did not significantly $(P>0.05)$ vary between enclosure and open-grazed sites (Table 5).

\section{Chemical Composition of Herbaceous Species}

The variation in chemical composition of herbaceous species in the study area is presented in Table 6 . The actual DM of herbaceous species was significantly $(P<$ 0.05 ) higher in area enclosure than in the open-grazed rangelands. The $\mathrm{CP}$ contents of herbaceous species were significantly $(P<0.05)$ lower in enclosure areas than in the open-grazed rangelands. The structural constituents (i.e., NDF, ADF and ADL) of herbaceous species in enclosure areas were significantly $(P<0.05)$ higher than in the opengrazed areas. 
Table 4: Floristic composition of herbaceous species by dry weight within enclosures vs. open-grazed areas in LegaHidha woreda of Bale zone, Ethiopia

\begin{tabular}{lcc}
\hline \multicolumn{1}{c}{ Species list } & Dry weight $\mathbf{~ g ~ m}^{-2}$ & by floristic composition \\
\hline Grasses & Enclosure & Open grazed \\
\hline Bothriochloa inscuipta & 0.37 & 0.32 \\
Brachiaria humidcola & 0.32 & 0.28 \\
Cenchrus ciliaris & 0.30 & 0.26 \\
Chloris pycnothrix & 0.00 & 0.20 \\
Chrysopogon plumulosus & 0.40 & 0.37 \\
Cynodon dactylon & 0.00 & 0.40 \\
Digitaria villosa & 0.35 & 0.28 \\
Enteropogon macrostachyus & 0.44 & 0.32 \\
Eragrostis ciliaris & 0.35 & 0.36 \\
Heteropogon contortus & 0.45 & 0.35 \\
Hyparrhenia hirta & 0.39 & 0.31 \\
Microchloa kunthii & 0.00 & 0.43 \\
Setaria paradox & 0.00 & 0.31 \\
Sporobolus pyramidalis & 0.34 & 0.32 \\
Sporobulus festivus & 0.30 & 0.31 \\
Tetrapogon cenchriformis & 0.42 & 0.00 \\
Themeda triandra & 0.42 & 0.37 \\
Tragus berternianus & 0.00 & 0.13 \\
\hline Legumes & & \\
Crotalaria spinosa & 0.29 & 0.16 \\
Tephrosia spps & 0.28 & 0.30 \\
\hline Others/Forbs & & \\
Achyranthus aspera L. & 0.28 & 0.27 \\
Belpharis spps & 0.16 & 0.35 \\
Commelina benghalensis L. & 0.20 & 0.16 \\
Cyperus rotandus & 0.00 & 0.30 \\
Ocimum basilicum & 0.28 & \\
Sida ovata Forssk. & 0.30 & \\
\hline
\end{tabular}

Table 5: Dry matter yield $\left(\mathrm{g} \mathrm{m}^{-2}\right)$ (Mean $\left.\pm \mathrm{SE}\right)$ as sampled in the different site and management in Lega-Hidha

\begin{tabular}{lllllll}
\hline \multirow{2}{*}{ Parameter } & \multicolumn{2}{c}{ Deraba } & \multicolumn{2}{c}{ D/J/ Gubisa } & \multicolumn{2}{c}{ Beltu } \\
\cline { 2 - 7 } & \multicolumn{1}{c}{ Enclosure } & $\begin{array}{c}\text { Open- } \\
\text { grazed }\end{array}$ & \multicolumn{1}{c}{ Enclosure } & $\begin{array}{c}\text { Open- } \\
\text { grazed }\end{array}$ & \multicolumn{1}{c}{ Enclosure } & $\begin{array}{c}\text { Open- } \\
\text { grazed }\end{array}$ \\
\hline Highly desirable grass & $43.69 \pm 10.59^{\mathrm{a}}$ & $4.96 \pm 1.23^{\mathrm{b}}$ & $11.20 \pm 4.6^{\mathrm{a}}$ & $10.15 \pm 2.81^{\mathrm{a}}$ & $7.70 \pm 2.28^{\mathrm{a}}$ & $8.64 \pm 2.33^{\mathrm{a}}$ \\
Intermediate desirable & $27.05 \pm 8.49^{\mathrm{a}}$ & $0.09 \pm 0.06^{\mathrm{b}}$ & $92.64 \pm 12.52^{\mathrm{a}}$ & $17.52 \pm 6.26^{\mathrm{b}}$ & $8.90 \pm 4.43^{\mathrm{a}}$ & $3.23 \pm 1.45^{\mathrm{a}}$ \\
grass & & & & & & \\
Less desirable grass & $67.37 \pm 13.84^{\mathrm{a}}$ & $2.22 \pm 0.82^{\mathrm{b}}$ & $46.89 \pm 11.97^{\mathrm{a}}$ & $13.82 \pm 2.91^{\mathrm{a}}$ & $74.88 \pm 10.75^{\mathrm{a}}$ & $2.65 \pm 1.12^{\mathrm{b}}$ \\
Total grass & $117.90 \pm 9.13^{\mathrm{a}}$ & $7.27 \pm 1.04^{\mathrm{b}}$ & $150.72 \pm 11.95^{\mathrm{a}}$ & $41.48 \pm 6.19^{\mathrm{b}}$ & $91.47 \pm 8.91^{\mathrm{a}}$ & $14.52 \pm 3.11^{\mathrm{b}}$ \\
Legumes & $1.97 \pm 0.84$ & $0.84 \pm 0.32$ & $1.20 \pm 0.71$ & $0.00 \pm 00$ & $0.38 \pm 0.21$ & $0.00 \pm 0.00$ \\
Forbs & $6.99 \pm 1.12^{\mathrm{a}}$ & $3.29 \pm 0.74^{\mathrm{b}}$ & $0.15 \pm 0.15^{\mathrm{a}}$ & $1.43 \pm 0.85^{\mathrm{a}}$ & $1.25 \pm 0.34^{\mathrm{a}}$ & $3.45 \pm 1.08^{\mathrm{b}}$ \\
Total biomass & $126.85 \pm 9.23^{\mathrm{a}}$ & $11.40 \pm 1.31^{\mathrm{b}}$ & $152.07 \pm 12.15^{\mathrm{a}}$ & $42.91 \pm 6.09^{\mathrm{b}}$ & $93.10 \pm 8.82^{\mathrm{a}}$ & $17.97 \pm 2.94^{\mathrm{b}}$ \\
\hline \multicolumn{2}{c}{ Mean in the same row for each parameter with different superscripts are significantly different $(P<0.05)$}
\end{tabular}

Table 6: Chemical composition (Mean \pm SE) and DM (\%) of herbaceous species at different sites and rangeland practices in Lega-Hidha woreda of Bale zone

\begin{tabular}{ccccccc}
\hline \multirow{2}{*}{ Parameter } & \multicolumn{2}{c}{ Deraba } & \multicolumn{2}{c}{ D/J/ Gubisa } & Beltu \\
\cline { 2 - 6 } & Enclosure & Open-grazed & Enclosure & Open- Grazed & Enclosure & Open-Grazed \\
\hline DM (\%) & $42.00 \pm 1.00^{\mathrm{a}}$ & $33.50 \pm 1.50^{\mathrm{b}}$ & $45.5 \pm 1.5^{\mathrm{a}}$ & $35.5 \pm 0.5 \pm 0.5^{\mathrm{b}}$ & $44.00 \pm 1.00^{\mathrm{a}}$ & $32.5 \pm 1.50^{\mathrm{b}}$ \\
Ash & $17.78 \pm 0.1 .05^{\mathrm{a}}$ & $10.81 \pm 0.60^{\mathrm{b}}$ & $12.59 \pm 0.78^{\mathrm{a}}$ & $9.70 \pm 1.44^{\mathrm{b}}$ & $15.09 \pm 0.68^{\mathrm{a}}$ & $10.65 \pm 0.52^{\mathrm{a}}$ \\
NDF & $67.13 \pm 0.65^{\mathrm{a}}$ & $61.04 \pm 0.49^{\mathrm{b}}$ & $64.79 \pm 0.78^{\mathrm{a}}$ & $54.69 \pm 1.44^{\mathrm{b}}$ & $63.78 \pm 0.66^{\mathrm{a}}$ & $58.45 \pm 082^{\mathrm{b}}$ \\
ADF & $35.45 \pm 0.12^{\mathrm{a}}$ & $31.68 \pm 0.19^{\mathrm{b}}$ & $35.49 \pm 0.38^{\mathrm{a}}$ & $29.97 \pm 0.00^{\mathrm{b}}$ & $35.13 \pm 0.51^{\mathrm{a}}$ & $29.74 \pm 1.01^{\mathrm{b}}$ \\
ADL & $9.81 \pm 0.60^{\mathrm{a}}$ & $6.58 \pm 0.05^{\mathrm{b}}$ & $10.53 \pm 0.29^{\mathrm{a}}$ & $6.73 \pm 0.12^{\mathrm{b}}$ & $10.16 \pm 0.88^{\mathrm{a}}$ & $6.03 \pm 0.81^{\mathrm{b}}$ \\
CP & $6.08 \pm 0.08^{\mathrm{b}}$ & $7.32 \pm 0.26^{\mathrm{a}}$ & $6.58 \pm 0.12^{\mathrm{b}}$ & $7.64 \pm 0.18^{\mathrm{a}}$ & $5.89 \pm 0.21^{\mathrm{b}}$ & $8.80 \pm 0.54^{\mathrm{a}}$ \\
\hline \multicolumn{7}{c}{ Mean in the same row for each parameter with different superscripts are significantly different $(P<0.05)$}
\end{tabular}

\section{Chemical Composition of Major Grass Species}

Table 7 presents the chemical composition of major grass species in the study sites. The actual DM of $H$. contortus was significantly $(P<0.05)$ higher than that of $B$. inscuipta. Similarly, the dry matter of $H$. contortus was significantly $(P<0.05)$ higher than $C$. plumulosus. The results of this study demonstrated that the $\mathrm{CP}$ and total Ash content of $C$. plumulosus was significantly $(P<0.05)$ 
higher than other grass species. The NDF content of $H$. contortus and $T$. triandra was significantly $(P<0.05)$ higher than other species while $H$. contortus had the highest ADF content than B. inscuipta and $C$. plumulosus. The ADL content of $B$. inscuipta and $C$. plumulosus were significantly $(P<0.05)$ higher than other species.

Table 7: Chemical Compositions (Mean \pm SE) of Major Grass Species in Lega-Hidha woreda of Bale zone, Ethiopia

\begin{tabular}{lllllll}
\hline & & \multicolumn{5}{c}{$\%$ DM } \\
\cline { 3 - 7 } \multicolumn{1}{c}{ Species } & DM (\%) & Ash & NDF & ADF & ADL & CP \\
\hline Heteropogon contortus & $40.67^{\mathrm{a}}$ & $11.31^{\mathrm{b}}$ & $64.08^{\mathrm{a}}$ & $35.44^{\mathrm{a}}$ & $5.28^{\mathrm{b}}$ & $7.04^{\mathrm{b}}$ \\
Bothriochloa inscuipta & $34.5^{\mathrm{b}}$ & $13.51^{\mathrm{ab}}$ & $60.76^{\mathrm{c}}$ & $33.16^{\mathrm{b}}$ & $6.31^{\mathrm{a}}$ & $7.81^{\mathrm{ab}}$ \\
Chrysopogon plumulosus & $38.55^{\mathrm{ab}}$ & $15.15^{\mathrm{a}}$ & $61.26^{\mathrm{b}}$ & $32.87^{\mathrm{b}}$ & $7.88^{\mathrm{a}}$ & $8.18^{\mathrm{a}}$ \\
Themeda triandra & $41.1^{\mathrm{a}}$ & $12.02^{\mathrm{b}}$ & $63.92^{\mathrm{a}}$ & $34.55^{\mathrm{a}}$ & $5.43^{\mathrm{b}}$ & $5.9^{\mathrm{c}}$ \\
SE & 0.86 & 0.40 & 0.45 & 0.35 & 0.37 & 0.24
\end{tabular}

Mean in the same column for each parameter with different superscripts are significantly different $(P<0.05)$

\section{DISCUSSION}

The Effect of Enclosure on Rangeland Condition

Grass species composition did not show any significant difference between the enclosure and opengrazed sites (management systems) except that of Delo/J/Gubisa. The probably explanation could be similarity of the effect of disturbance by livestock or wild herbivory in both cases. This implies that the enclosure areas are only few years since establishment and that might also be another reason for the lack of significance differences between the two management systems. The result of the present study is in agreement with the report by Amsalu (2000). The highest score for rangeland condition was recorded within enclosures. However, grass species composition did not show any significant variation between enclosures and open-grazed rangelands. In the current study, the low values for basal cover, litter cover, number of seedlings and age distribution of dominant grasses in the open-grazed sites could reflect the impact of continuous grazing and recurrent drought. Similarly, Van der Westhizen et al. (2001) argued that in arid and semi-arid rangelands, these parameters are greatly influenced by the effects of gazing pressure, drought and rainfall variability.

Repeated grazing and prolonged drought might lead to a reduction in herbaceous species composition and diversity, which might accelerate decline in rangeland condition. As reported by Angassa (2014) heavy grazing pressure may reduce plant species composition and basal cover. On the other hand, the highest scores for basal cover, age distribution of dominant grasses and number of seedlings were recorded in enclosed sites reflecting the benefits of reduced disturbance such as the effects of heavy grazing, trampling and inappropriate management interventions (Amaha, 2006). In addition, continuous grazing affects the amount of plant litter at the soil surface and exerts indirect pressures on the germination and seedling establishment patterns (Amsalu, 2000; Teshome, 2007; Amaha 2006; Lishan, 2007; Desalew, 2008).

The eroded and compacted soil in the open-grazed (i.e., sites with high grazing pressure) has low basal cover, higher bare ground cover and could lead to its compactness and loss of the soil. The observed low score for soil condition in some sampling plots could be attributed to many years of continuous grazing and loss of herbaceous species. Amsalu (2000) has reported that increased grazing pressure aggravates the hoof effect, which increases the soil bulk density resulting in reduced infiltration. Teshome (2007) has found low values for basal cover, litter cover, number of grass seedlings and age distribution in heavily grazed sites vs. the medium and light grazed sites reflecting the impacts of recurrent drought and grazing pressure in heavily grazed sites. This implies that decline in the rangeland condition in the opengrazed areas have a direct negative influence on livestock production and livelihood of inhabitants in the district.

\section{The Effect of Enclosure on Herbaceous Species Composition}

The findings of this study confirm that increased grazing had a significant effect on herbaceous species composition and rangeland condition. Hence, examining herbaceous species composition on the basis of grazing pressure might show a better picture of the effect of grazing on individual herbaceous species. This study shows that open-grazed sites had less herbaceous species abundance, which probably reflects the impact of increased grazing pressure on most herbaceous species as reported by previous researchers (Amsalu, 2000; Teshome, 2007; Desalew, 2008; Angassa, 2014). Herbaceous species composition in the enclosure sites was in a better condition than those in the open grazing sites. Nevertheless, certain key species were tolerant of grazing and become more dominant and/or common in the open-grazed areas. Moreover, the observed higher species abundance in the enclosure areas is probably related to fewer disturbances by livestock grazing (Angassa and Oba, 2008). Similarly, previous studies (Angassa and Oba, 2010; Angassa, 2014) have shown the connection between herbaceous species and grazing intensity, suggesting that more species abundance under light to moderate-grazed areas reflect the effect of heavy grazing on individual species. The decline in the proportion of herbaceous species abundance due to the effect of grazing pressure is consistent with previous studies (Angassa, 1999; Oba et al., 2000; Amsalu, 2000; Teshoma, 2007)

The orderly change of species composition from highly palatable to less palatable with the increase of grazing pressure is similar to the reports of others (Amaha, 2006; Admasu, 2006; Amsalu, 2000; Desalew, 2008). Under continuous and increased grazing pressure, palatable plants (decreasers) would die and with the death of decreasers less palatable plants (increasers) become dominant. 
Mengistu Asrat et alo,

The Effect of Enclosure on Dry-matter Yield of Herbaceous Species

The result of the current study has shown that the total DM yield and DM of individual grass species were higher in enclosures than in the open-grazed areas. The impact of management factors may be the main reasons for the significant difference in terms of herbaceous biomass between the enclosure and open-grazed areas. The low DM yields of forage in the open grazed sites as compared to enclosure areas corresponded with the reports of Teshome (2007), suggesting that rangelands in poor condition had low forage production with less desirable forage than those rangeland in good conditions. Similarly, the results of this study is in agreement with earlier reports (Amsalu, 2000; Amaha, 2006; Gemedo et al., 2006; Teklu et al., 2010; Shankute et al., 2011). Legumes and forbs were not significantly different between enclosure rangeland and open grazing areas. This similarity might be due to the tolerance of certain species under increased grazing pressure. The findings of this study show that open grazing site had low dry matter yield of herbaceous species, which might be attributed to the poor management practices, effects of recurrent drought and increased grazing pressure. The present finding is in line with the work of Gemedo et al. (2006), suggesting that rangelands in poor condition had low forage production with less desirable than rangelands in good condition.

\section{Chemical Composition of Herbaceous Species}

The results of the present finding indicate that the potentiality of sites significantly influenced the nutritive value of herbaceous species among the different land management site in Lega-Hidha woreda. The results of this study is in consistent with the findings of others (Teka et al., 2012; Mittal et al., 2012) who studied the nutritional quality of grass species in Borana rangeland and India, respectively. The result of this study showed that differences in land use management can greatly influence the nutritive value of herbaceous plants in arid and semiarid environments. The possible explanations for the observed variation among sites may be due to differences in soil nutrient status and intensity of grazing, where most palatable species may be affected by excessive grazing.

The current findings show that open grazing rangeland sites had higher content of CP than enclosed sites. The probable reason for the highest $\mathrm{CP}$ content in the opengrazed rangeland sites may be attributed to the frequent removal of old pastures by grazers and deposition of manure to improve the soil fertility and plant nutrient content indirectly, which also reported by Teka et al. (2012). However, higher NDF and ADF were recorded within area enclosures than open grazed rangeland areas. The possible explanation for the highest content of fibers could be due to lack of proper time of harvesting or utilization by grazing animals at the proper stage of maturity of the forage plant (Teka et al., 2012; Shankute et al., 2011). Thus, the low accumulation of CP and increased level of fibers are an indication of poor quality of forage (Teka et al., 2012). It seems that the chemical composition of herbaceous forage is more influenced by the stage of maturity than any other factors.

\section{Chemical Composition of Major Grass Species}

The current study indicates that among the different grass species, there are variations in terms of their nutritional qualities. This could be due to inherent nature
Sci. Technol. Arts Res. J., April-June 2015, 4(2): 79-88

of the species, morphological and anatomical differences among grass species. Species specific feed resource and site differences are known to be the major factors in affecting the nutritive value of native forage species (Mahala et al., 2009; Subhalakshmi et al., 2011). Teka et al. (2012) reported that variation in the nutritive value of herbaceous species might also be attributed to sites' potential in terms of differences in soil characteristics and temperature conditions. Similarly, other studies (Desalew, 2008; Teklu et al., 2010) have also indicate that differences in the nutrient content between and within species could be attributed to the inherent nature of a particular species. Naturally, there could be morphological and anatomical differences within the herbaceous species. Mathur et al. (1991) indicate that most grasses and tree leaves in arid environments are low in nutritive values mainly because of the high contents of lignin and relatively indigestible cellulose and hemi-cellulose.

\section{CONCLUSIONS}

The present finding showed that the status of rangeland in the open-grazed areas was in poor condition due to increased grazing pressure while the status of enclosure areas was in a good condition as a result of reduced disturbances. From the result of this study, we suggest that enclosures are potential options for future rangeland improvement and conservation of key forage species. Generally, the chemical compositions of herbaceous plants were greatly varied by sites and among species.

\section{Conflict of Interest}

Authors declared no conflict of interest.

\section{REFERENCES}

Abule, E., Snyman, H.A, Smit, G.N. (2007). Rangeland evaluation in the middle Awash Valley of Ethiopia: Herbaceous vegetation cover. Journal of Arid Environment 70: 253-271.

Admasu, T. (2006). Pastoralists' perceptions on rangelivestock management practices and rangeland assessment in Hamer and Benna-Tsemay districts of South Omo Zone. MSc Thesis. Alemaya University, Dire Dewa, Ethiopia. 159 pp.

Ahmed, H. (2003). Assessment and evaluation of utilization practices of natural pastures and other forages in Basona Worana wereda of North Shoa Zone. MSc Thesis. Alemaya University, Dire Dewa, Ethiopia. 174pp.

Alemayehu, M. (2004). Rangelands Biodiversity: Concepts, Approaches and the Way Forward. Addis Ababa, Ethiopia. 109pp.

Alemayehu, M. (2005). Rangelands: Biodiversity Conservation and Management and Inventory and Monitoring. Addis Ababa University, Faculty of Science, Addis Ababa, Ethiopia.

Amaha, K. (2006). Characterization of rangeland resources and dynamics of the pastoral production system in the Somali region of eastern Ethiopia. Ph.D Thesis. Free State University, Bloemfontein, South Africa. 249 pp.

Amsalu, S. (2000). Herbaceous species composition, dry matter and condition of the major grazing areas in the middle rift valley, Ethiopia. M.Sc Thesis. Alemaya University, Dire Dewa, Ethiopia. 159 pp.

Amsalu, S., Baars, R.M.T. (2002). Grass composition and rangeland condition of the major grazing areas in the mid 
Mengistu Asrat et alo,

rift valley of Ethiopia. African Range and Forage Sciences 9: 161-166.

Angassa, A. (1999). Range condition traditional grazing management system in Borena. M.sc. Thesis. Alemaya University, Dire Dewa, Ethiopia. 55pp.

Angassa, A., Oba, G. (2008). Herder perceptions on impacts of range enclosures, crop farming, fire ban and bush encroachment on the rangelands of Borana, southern Ethiopia. Human Ecology 36: 201-215.

Angassa, A., Oba, G. (2010). Effect of grazing pressure, age of enclosures and seasonality on bush cover dynamics and vegetation composition in Southern Ethiopia. Journal of Arid Environments 74: 111-120.

Angassa, A. (2014). Effects of grazing intensity and bush encroachment on herbaceous specie and rangeland condition in southern Ethiopia. Land degradation and Development 25: 438-451.

AOAC (Association of Official Analytical Chemists). (2000). Official methods of analysis (15th ed). Inc., Washington D.C., USA.

Baars, R.M.T., Chileshe, E.C., Kalokoni, D.R. (1997). Technical notes: Range condition in high cattle density areas in the Western province of Zambia. Tropicalgrasslads 31: 569-573.

Belaynesh, D. (2006). Floristic composition and diversity of the vegetation, soil seed bank flora and condition of the rangelands of the Jijiga zone, Somali Regional State, Ethiopia. MSc Thesis. Alemaya University, Dire Dewa, Ethiopia. 144pp.

Desalew, T. (2008). Assessment of Feed Resources and Rangeland Condition in Metema District on North Gonder Zone, Ethiopia. MSc Thesis. Haramaya University, Dire Dewa, Ethiopia. 161pp.

Friedel, M. H. (1991). Range Condition Assessment and the Concept of Thresholds: views point. Journal of Range Management 44: 422-426.

Fromann, B., Persson, S. (1974). An illustrated guide to the grasses of Ethiopia. CADU (Chillalo Agricultural Development Unit): Assella, Ethiopia. 231pp.

Gemedo, D. T., Maass, B.L., Isselstein, J. (2006). Rangeland condition and trend in the semi-arid Borana lowlands, southern Oromia, Ethiopia. African Journal of Range and Forage Science 23: 49-58.

Lishan, T. (2007). Woody and herbaceous species composition and the condition of the rangelands in Shinile zone of Somali regional state, Ethiopia. MSc. Thesis. Haramaya University, Ethiopia. 136 pp.

Mahala, A.G., Nsahlai, I.V., Basha, N.A.D., Mohammed L.A. (2009). Nutritive evaluation of natural pasture at early and late rainfall season in Kordofan and Butana, Sudan. Australian Journal of Basic and Applied Science 3: 43274332.

Mekuria, W., Yami, M. (2013). Changes in woody species composition following establishing exclosures on grazing lands in the lowlands of northern Ethiopia. African Journal of Environmental Science and Technology 7(1): 30-40.
Sci. Technol. Arts Res. J., April-June 2015, 4(2): 79-88

Mittal, G.K., Sharma, K.M., Maheshwari, M.L., Barsaul, C.S. (2012). Chemical composition of some natural available fodder resources in Hill area of Chakrata (Utter Pradesh). Indian Journal of Animal Nutrition 5: 341-344.

Oba, G., Post, E., Syvertsen, P.O., Stenseth, N.C. (2000). Bush cover and range condition assessments in relation to landscape and grazing in southern Ethiopia. Landscape Ecology 15: 535-546.

Pastoral Areas Development Study (PADS). (2004). Pastoral Areas Development Plan (PADP), General executive summary, Ministry of Agriculture and Rural Development, Addis Ababa, Ethiopia. 258pp.

Shenkute, B., Abubeker H., Abule, E., Tadese, A., Nura, A., (2011). Identification of potential untapped herbaceous flora in the mid rift valley of Ethiopia and their nutritive value. African Journal of Agricultural research 6 (17): 4153-4158.

Solomon, T., Snyman, H.A., Smit, G.N. (2006). Rangeland dynamics in southern Ethiopia: (3). Assessment of rangeland condition in relation to land-use and distance from water in semi-arid Borana rangelands. Journal of Environmental Management 85 (2):453-460.

Subhalakshmi, B., Bhuyan, R., Sama, D.N., Sharma, K.K., Bora, A. (2011). Effect of variety and stag of harvest on yield, chemical composition and invitro digestibility of hybrid Napier (Pennisetum purpureum x P. americanum). Indian Journal of Animal Nutrition 28: 418-420.

Tainton, N.M. (1981). The Assessment of Veld Condition. In: N.M. Tainton (Ed).Veld and pasture management in South Africa. Shutter and shooter Ltd: Pietermaritzburg , South Africa. 255pp.

Taklu, B., Negessa, T., Angassa, A. (2010). Effect of farming system on floristic composition, yield and nutritional content of forages at the natural pasture of Assosa Zone. Tropical and Subtropical Agroecosystem 12: 583 -592.

Teka, H., Casper, M.I., Angassa, A., Hassen, A. (2012). Effect of seasonal variation on the nutritional quality of key herbaceous species in semi-arid areas of Borana, Ethiopia. Indian Journal of Animal Nutrition 29 (4): 32433.

Teshome, A. (2007). Traditional utilization practices and condition assessment of then rangelands in Rayitu district of Bale zone, Ethiopia. MSc Thesis. Haramaya University, Dire Dewa, Ethiopia. 129pp.

Van der Westhuizen, H.C., Van Rensburg, W.L.J., Snyman, H.A. (1999). The quantification of rangeland condition in semi-arid grassland of Southern Africa. African Journal of Range and Forage Science 16: 9-21.

Van Soest, P.J., Robertson, J.B. (1985). Analysis of Forages and Fibrous Feeds. Laboratory Manual for Animal Science 613, Cornell University, Ithaca, New York. 202 pp.

Yayneshet, T., Eik, L.O., Moe, S.R. (2009). Seasonal variations in the chemical composition and dry matter degradability of enclosure forages in the semi-arid region of Northern Ethiopia. Animal Feed Science and Technology 148: 12-33. 